\title{
SOCIETY APPOINTS NEW SECRETARY-TREASURER
}

Following the resignation of Clarence Cooper, David Vaughan Love was appointed Secretary-Treasurer of the Canadian Society of Forest Eng. ineers in November, 1948. D. V. Love was born in St. John, N.B., and graduated in Forestry from the University of New Brunswick in 1941. He spent three and a half years in the R.C.N.V.R. as Navigation Offcer and after demobilization took postgraduate work at the School of Forestry and Conservation, University of Michigan, Ann Arbor, where he was awarded the Master of Forestry degree in June, 1946.

During the summer of 1946 he carried on cost control and volume table construction studies for Marathon Paper Mills of Canada at Port Arthur. He was appointed Lecturer in the Faculty of Forestry, University of Toronto, in July, 1946, and Assistant Professor of Forestry in July, 1947, and gives the first and second year courses in Forest Mensuration.

During the summer of $1947 \mathrm{Mr}$. Love instructed at the Ontario Forest Ranger School and later in the season worked on management plans for the Standard Chemical Company. In 1948 he worked on milling cost studies for the Ontario Department of Lands and Forests, assisted the late Professor Matthews with his course in forest production economics, and worked on plans for the Department covering the salvage of timber in the Mississagi fire area.

Professor Love is married and has one daughter. He has been a member of the Society since February, 1948.

\section{FOREST RESOURCES OF THE WORLD}

The above is the title of an interesting and exhaustive report compiled by the Division of Forestry and Forest Products of the Food and Agriculture Organization of the United Nations. This report was first published in Unasylva, Vol. II No. 4 July-August 1948, and is now available as a reprint which can be obtained for twenty-five cents from either FAO, 1201 Connecticut Avenue, N.W., Washington, or from the Ryerson Press, Toronto. It is suggested that all foresters should have a copy of this exceedingly useful publication. 